\title{
A Rare Complication of Arthroplasty: Metallosis
}

\author{
Nadir Bir Artroplasti Komplikasyonu: Metallozis
}

\author{
Cansu Benli Işık, Halide Nur Ürer*, Saime Gül Barut, Mustafa Fehmi Akyıldız* , Doğan Atlıhan** \\ University of Health Sciences Haseki Training and Research Hospital, Clinic of Pathology, Istanbul, Turkey \\ *Yedikule Hospital for Chest Disease and Thoracic Surgery, Clinic of Pathology, Istanbul, Turkey \\ **University of Health Sciences Haseki Training and Research Hospital, Clinic of Orthopaedics and Traumatology, Istanbul, Turkey
}

\begin{abstract}
Metallic prosthetic materials are used in place of bones and joints that have lost their function. Metallosis is a rare complication of the arthroplasty where metallic prostheses are used. It is defined as the infiltration of friction-related metallic debris into periprosthetic bones and soft tissues. Its histology is characterized by widespread lymphoplasmacytic and histiocytic infiltration around metal debris, foreign body giant cells, metal particles, extracellular metal deposits and intracytoplasmic debris in giant cells. Since it can be confused with malignant melanoma due to the presence of pigment as well as, giant cell tumors of the soft tissues and bones, care should be taken in the examination of post-arthroplastic materials. For this reason, we found it worthwhile to present two rare cases of post-arthroplasty metallosis, one developed in the knee joint and the other in the hip joint.
\end{abstract}

Keywords: Metallosis, arthroplasty, complication, foreign body reaction

\begin{abstract}
İşlevini yerine getiremeyen kemik ve eklemlerin yerine metalik prostetik materyaller kullanılabilmektedir. Metallozis, metalik protezlerin kullanıldığı artroplastik tedavinin nadir gelişen bir komplikasyonudur ve periprostetik kemik ve yumuşak dokuya metalik aşınma debrislerinin infiltrasyonu olarak tanımlanır. Histolojisinde metal debris etrafında yaygın lenfoplazmasitik ve histiositik infiltrasyon, yabancı cisim dev hücreler, metal partiküller, ekstraselüler metal depozitler ve dev hücrelerde intrasitoplazmik debris görülebilir. Histolojik olarak yumuşak dokunun ve kemiğin dev hücreli tümörleri ile pigment varlığı nedeniyle malign melanomla karışabileceği için post-artroplastik materyallerin incelenmesinde dikkatli olunmalıdır. Bu nedenle biri diz diğeri kalça ekleminde gelişmiş iki nadir post-artroplastik metallozis olgusunu sunmaya değer bulduk.
\end{abstract}

Anahtar Sözcükler: Metallozis, artroplasti, komplikasyon, yabancı cisim reaksiyonu

\section{Introduction}

Metallic prosthetic materials are used for restoring joint and bone functions permanently or temporarily. Metallosis is a rare and late complication of arthroplasty involving the use of metallic prosthetics (1). The condition is defined as the infiltration of metallic debris into periprosthetic joints, bones and soft tissues as a result of the wear caused by friction of metallic surfaces against each other (2). Alongside the loss of functionality in the prosthesis, a granulation develops in the tissue accompanied by reactional foreign body giant cells and macrophages. A thickening and scar tissue develop in the joint capsule due to inflammation (3). The incidence of metallosis gradually decreases as a result of using less reactional prosthetic materials with developing technology.

We described in our paper two cases of postarthroplasty metallosis in the light of the literature.

\section{Case}

Our first case was an 84-year-old female patient. She had undergone a left total knee arthroplasty 15 years ago. Swelling and pain developed in the same knee during the last year. With increasing limitation of motion, the patient presented to the orthopedics clinic. Imaging methods revealed loosening, fracture and increased soft tissue density in the tibial and femoral components (Figure 1). During the operation, a widespread color change was seen in the joint due to metal-on-metal rubbing upon the

Address for Correspondence/Yazışma Adresi: Cansu Benli Işık

University of Health Sciences Haseki Training and Research Hospital, Clinic of Pathology, İstanbul, Turkey

Phone: +90 2125294400 E-mail: cansubenli19@hotmail.com

Received/Geliş Tarihi: 24 November 2016 Accepted/Kabul Tarihi: 20 December 2016

This study was presented as a poster in the $25^{\text {th }}$ National Congress of Pathology on November 15, 2015 in Bursa.

Copyright 2017 by The Medical Bulletin of University of Health Sciences Haseki Training and Research Hospital The Medical Bulletin of Haseki published by Galenos Yayınevi. 'Telif Hakkı 2017 Sağlik Bilimleri Üniversitesi Haseki Eğitim ve Araştırma Hastanesi Haseki Tıp Bülteni, Galenos Yayınevi tarafindan basılmıştr. 


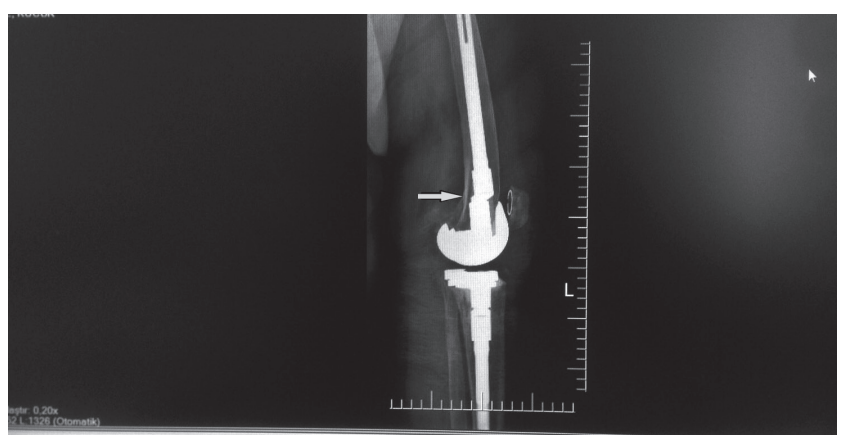

Figure 1. The fracture in the femoral component before the operation

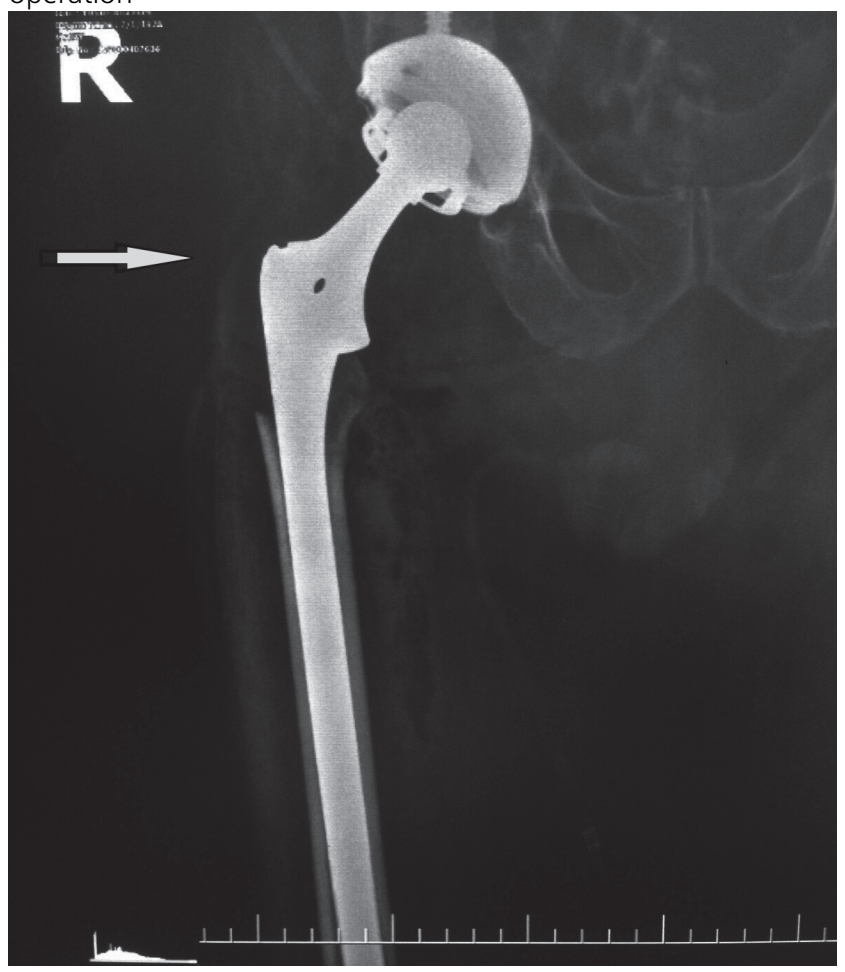

Figure 2. Osteolysis in the proximal femoral component



Figure 3. Diffuse color change to black in the soft tissue surrounding the joint, during the operation breaking of the tibial polyethylene insert and a fracture in the tibial and femoral components. The prostheses were removed and the joint was debrided. The femoral component and tibial base plate were placed and the operation was completed.

Our second case was an 87-year-old male patient. He had a total hip prosthesis approximately eight years ago. Pain, increased heat and movement restriction had developed in the last two years before he presented to the orthopedics clinic. On his examination, palpations showed that he had pain in his right hip and his prosthesis seemed to have lost its function. On his preoperative scans, the femoral head was seen to have migrated to superior within the acetabular component due to the wear in polyethylene. There was widespread osteolysis in the proximal femoral component (Figure 2). Diffuse color change to black was observed in the soft tissue surrounding the joint during the operation (Figure 3). Fracture was found in the superior of the acetabular component and excessive osteolysis associated with metallosis in his trochanter major and minor. Reactional tissues were debrided and the prosthesis removed before administering a revision arthroplasty.

Macroscopic findings in both cases demonstrated irregular comminuted tissue pieces of moderate hardness with some surfaces in bright membranous appearance including many areas in grey-black color.

Microscopic examination showed a structure consisting of broad nodular and papillary extensions (Figure 4a, 4b). Widespread black pigmentation (Figure 5) was observed in the extracellular and multinuclear giant cells on the fibrotic background that seemed rich by cells, as well as occasional foam-like cytoplasmic histiocyte accumulations and lymphocytes (Figure 6). Fibrosis-surrounded necrotic

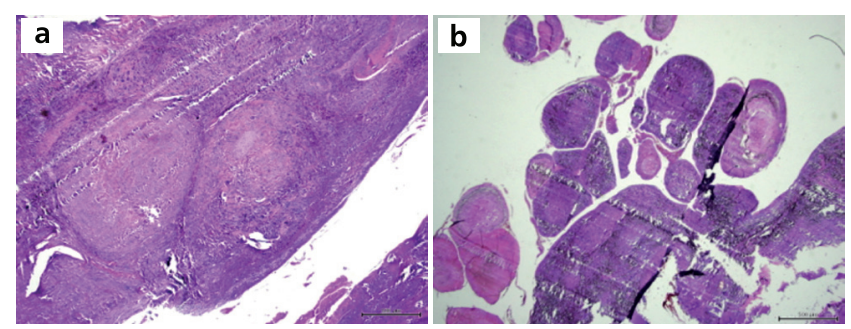

Figure 4. Broad nodular and papillary extensions

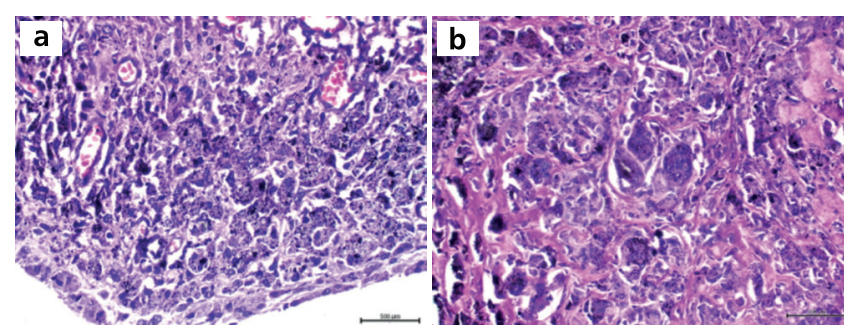

Figure 5. Presence of the black pigment in the multinuclear giant cells and extracellular region 
nodules were found in rare occasions. Additionally, refractile crystalloid fragments were seen in some multinuclear giant cell cytoplasms in our first case (Figure 7).

The findings were compatible with foreign body giant cell reaction associated with metallosis, intensive metal build-up and synovitis. We defined the lesions as postarthroplasty metallosis.

\section{Discussion}

Post-arthroplasty metallosis is a complication developings as a result of the accumulation of metallic debris in periprosthetic soft tissue due to long-term use of a joint prosthesis with metallic components. Besides the joint capsule and cavity, it can also affect extraarticular tissues. It is common particularly when prostheses with titanium components are used (4). Although it is mostly seen in the knee and hip joints, its occurrence has also been reported in other regions such as shoulders, wrists and ankles (4).

Metallosis may cause pain, joint effusions and increased serum metal ion levels, and changing of color to grey in the joint tissues. However, effusions and color changes can hardly be detected in clinical inspections due to the increase in soft tissue (3). Although there was no color change in the knee and hip skins in our patients, the

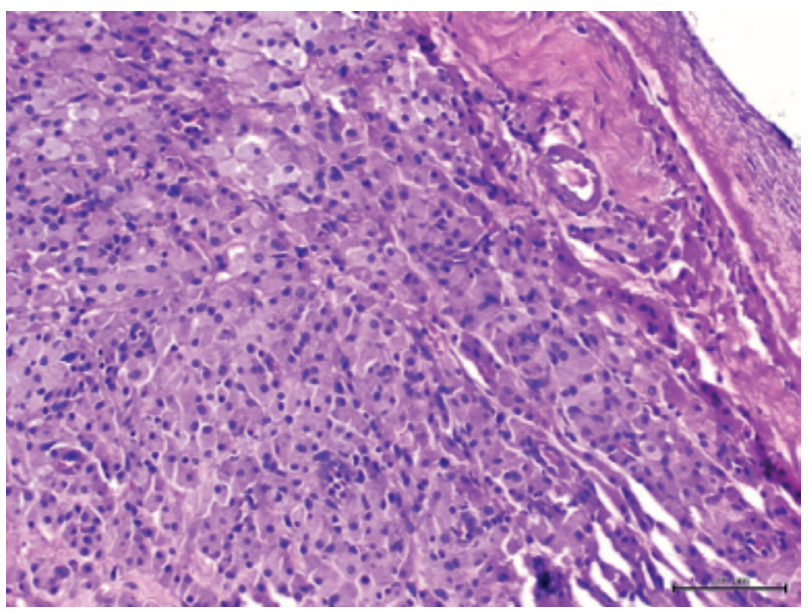

Figure 6. Accumulation of foamy cytoplasmic histiocytes
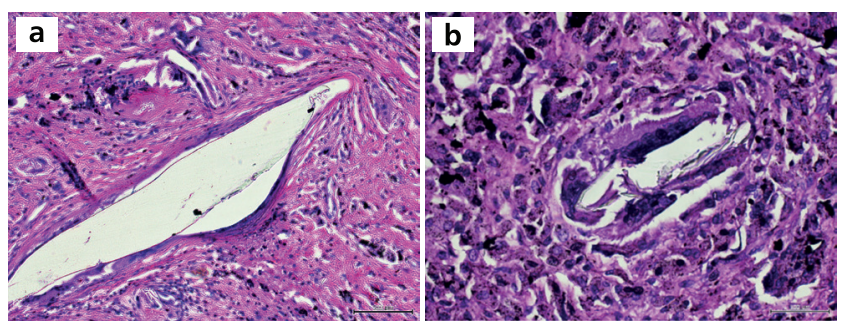

Figure 7. Refractile crystalloid fragments in some multinuclear giant cell cytoplasms macroscopic examination of the resected tissues revealed a color change to grey-black.

Metal hypersensitivity, direct toxic effects and synovitis associated with particle induction are thought to play a role in its physiopathology $(2,4)$. Widespread lymphocytic, histiocytic and plasmacytic infiltration around metal debris, foreign body giant cells, metal particles and extracellular metal deposits, as well as intracytoplasmic debris in giant cells can be seen in its histology. Inflammatory $T$ lymphocytes can infiltrate synovium, causing synovial hyperplasia (5).

Without considering the importance of inflammation, Fujishiro et al. (6) have shown a positive correlation between widespread diffuse lymphocytic infiltration with metallic debris. Although not specific to it, synovial necrosis is frequent in metallosis (7). Intensive black pigment, synovial necrosis and widespread lymphocytic inflammation were present in our patients.

Malignant melanoma and giant cell tumor of soft tissues and bones should be considered in the histopathological differential diagnosis of post-arthroplasty metallosis due to giant cells and the presence of pigments. Metallosis is distinguished from other diseases in its lack of morphology by fusiform, round and stromal cells, osteoid formation and melanin.

\section{Conclusion}

Metallosis is an inflammatory disease occurrings in post-arthroplastic bone joints and soft tissues due to accumulation of metal. Loss of function occurs in the prosthesis. The final diagnosis of the disease is made based on histopathological findings.

\section{Ethics}

Peer-review: Externally peer-reviewed.

\section{Authorship Contributions}

Surgical and Medical Practices: M.F.A., D.A., C.B.I. Concept: C.B.I., H.N.Ü. Design: C.B.I. Data Collection or Processing: C.B.I. Analysis or Interpretation: H.N.Ü., S.G.B., C.B.I. Literature Search: C.B.I. Writing: C.B.I., H.N.Ü.

Conflict of Interest: No conflict of interest was declared by the authors.

Financial Disclosure: The authors declared that this study received no financial support.

\section{References}

1. Cipriano CA, Issack PS, Beksac B, Della Valle AG, Sculco TP, Salvati EA. Metallosis after metal-on-polyethylene total hip arthroplasty. Am J Orthop (Belle Mead NJ) 2008;37:18-25.

2. Özkurt B, Tabak AY. Metallic biomaterials and metallosis. TOTBID Dergisi 2011;10:83-6. 
3. Jayasekera N, Gouk C, Patel A, Eyres K. Apparent Skin Discoloration about the Knee Joint: A Rare Sequela of Metallosis after Total Knee Replacement. Case Rep Orthop 2015;2015:891-904.

4. Romesburg JW, Wasserman $\mathrm{PL}$, Schoppe $\mathrm{CH}$. Metallosis and Metal-induced synovitis following total knee artroplasty: Review of radiographic and CT findings. J Radiol Case Rep 2010;4:7-17.

5. Schiavone Panni A, Vasso M, Cerciello S, Maccauro G. Metallosis following knee arthroplasty: a histological and immunohistochemical study. Int J Immunopathol Pharmacol 2011;24:711-9.

6. Fujishiro T, Moojen DJ, Kobayashi N, Dhert WJ, Bauer TW. Perivascular ve diffuse lymphocytic inflammation are not spesific for failed metal-on-metal hip implants. Clin Orthop Relat Res 2011;469:1127-33.

7. Von Domarus C, Rosenberg JP, Rüther W, Zustin J. Necrobiosis and T-lymphocyte infiltration in retrieved aseptically loosened metal-on-polyethylene arthroplasties. Acta Orthop 2011;82:596-601. 